\title{
Cavernous sinus thrombosis
}

\section{Trombose parcial do seio cavernoso}

Filipe Mira ${ }^{1}$, Bruno Costa ${ }^{2}$, Catarina Paiva ${ }^{3}$, Rui Andrês ${ }^{1}$,António Loureiro ${ }^{4}$

\begin{abstract}
Cavernous sinus thrombosis (CST) is a rare condition, usually results from a late complication of an infection of the paranasal sinuses. Other causes include prothrombotic disorders, anemia and trauma. The signs and symptoms are extremely varied and nonspecific, being the diagnosis made through magnetic resonance imaging (MRI). The authors present a 75-year-old woman, admitted in the emergency room complaining of ocular pain in the right eye $(R E)$, red eye and frontal headache. She presented on ophthalmic examination of the $R E$ : dilated episcleral vessels, nuclear cataract and a relative afferent pupillary defect. Fundoscopy examination of the RE revealed disc edema with nasal disc margin blurred, small dot hemorrhages and vascular tortuosity. The MRI angiography confirmed the diagnosis and the patient was treated with low molecular weight heparin. Despite treatment of CST is directed to the causal situation, being shown that anticoagulation is associated with reduction in mortality.
\end{abstract}

Keywords: Sinus thrombosis, intracranial; Anticoagulation; Magnetic resonance imaging; Case reports

\section{Resumo}

A trombose do seio cavernoso (TSC) é uma situação clínica rara, resultando normalmente da complicação de um processo infeccioso dos seios paranasais. Outras causas incluem alterações pró-trombóticas, anemia e trauma. Os sinais e sintomas são extremamente variados e inespecíficos, sendo o seu diagnóstico efetuado através de ressonância magnética nuclear (RMN). Os autores apresentam um caso clínico de uma doente com 75 anos de idade, que recorre ao serviço de urgência devido à dor em olho direito vermelho associado à cefaléias frontais com quatro dias de evolução. Ao exame oftalmológico observou-se defeito pupilar aferente relativo no olho direito (OD); na biomicroscopia vasos episclerais dilatados, catarata nuclear e à fundoscopia um edema discreto da papila com apagamento do rebordo nasal, hemorragias punctiformes dispersas e tortuosidade vascular em OD. A realização de angio-RMN confirmou o diagnóstico tendo a doente sido tratada com enoxaparina. Apesar do tratamento da TSC ser um tratamento etiológico, foi demonstrado que a anticoagulação está associada à diminuição da taxa de mortalidade.

Desctritores: Trombose dos seios intracranianos; Anticoagulação; Imagem por Ressonância magnética; Relatos de casos

1,2,3,4 Coimbra Hospital Centre (CHC), Portugal.

The authors declare no conflict of interest.

Received for publication 29/8/2011 - Acceped for publication 24/4/2012 


\section{INTRODUCTION}

$\mathbf{C}$ avernous sinus thrombosis (CST) is a rare condition, with few cases described in the literature ${ }^{(1)}$. It can be classified as septic or aseptic, depending on its aetiology. The septic form is the most common, being usually associated with infectious processes of the paranasal sinuses, face and ears ${ }^{(2)}$. The aseptic form is associated with trauma, thromboembolic events (increased factor VIII, reduced factor V Leiden and protein $\mathrm{C}$ and $\mathrm{S})$, dehydration and anaemia, among others ${ }^{(3,4)}$.

The clinical presentation is nonspecific and can include ophthalmoplegia, red eye, headache, coma, and even death ${ }^{(5)}$.

The mortality rate has dropped from almost $100 \%$ before the advent of antibiotics to less than $30 \%$ at present ${ }^{(2)}$.

Diagnosis is done by imaging studies, particularly magnetic resonance angiography (MRA) ${ }^{(6)}$.

This paper presents a case of partial thrombosis of the right cavernous sinus.

\section{Case Report}

A 75-year-old female patient sought the emergency department with a red right eye (RE), eye pain and frontal headache starting about four days earlier. She had been previously seen and treated with norfloxacin eye drops. The patient had a history of obesity. Ophthalmic examination showed a corrected visual acuity of $6 / 10$ in the RE and 7/10 in the left eye (LE); Biomicroscopy of the RE showed dilatation and congestion of episcleral vessels, especially in the nasal quadrant, and nuclear cataract (Figure 1A); Fundus examination of the RE showed papilloedema with a blurred nasal edge, scattered punctate haemorrhages and vascular tortuosity. Intraocular pressure was $13 \mathrm{mmHg}$ in both eyes (BE). Examination of the LE found no significant changes. Neurological and physical examination were also normal.

The patient underwent contrast-enhanced computed tomography (CT) which found “...discrete spontaneous heterogeneity of the right cavernous sinus suggesting a filling defect after contrast administration." (Figure 1B). She then underwent MRA, which found "...asymmetric cavernous sinuses with bulging of the right cavernous sinus wall. A filling defect was noted after contrast administration" (Figure 2A). T1weighted MRI also found that the calibre of the right superior ophthalmic vein was increased (Figure 2B).

The patient was admitted to the Neurology Department, where a complete blood count, biochemical tests, microbiology, serology, studies of prothrombotic factors, autoimmunity, and immunochemical factors found no changes.

She was treated with topical fluorometholone 1 drop every 8 hours and enoxaparin $60 \mathrm{mg}$ subcutaneously for 10 days, followed by warfarin $5 \mathrm{mg} /$ day. At hospital discharge she was asymptomatic, being prescribed warfarin $5 \mathrm{mg}$ (1 tablet alternating with $1 / 2$ tablet).

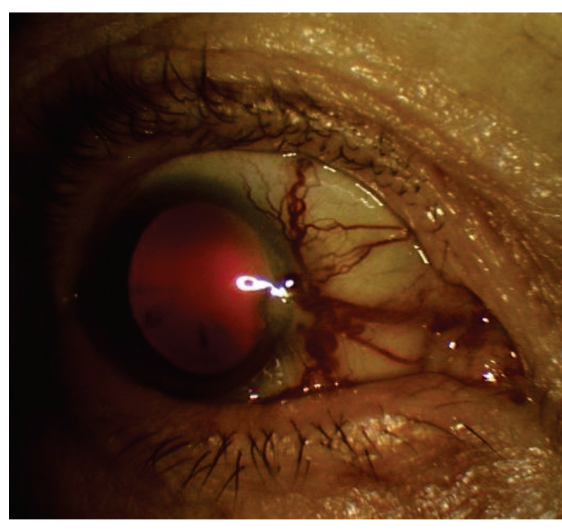

Figure 1A: Congested episcleral vessels

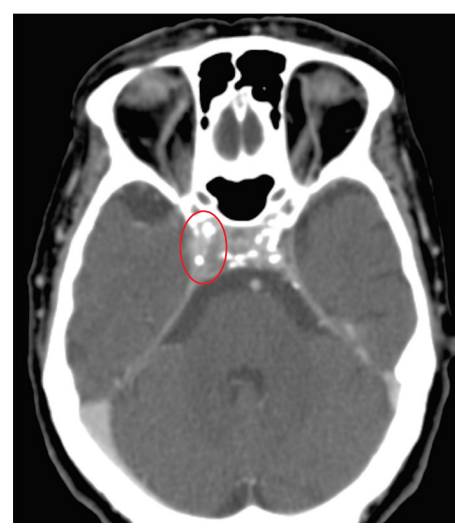

Figure 1B: Axial CT angiography suggesting a filling defect after contrast administration.

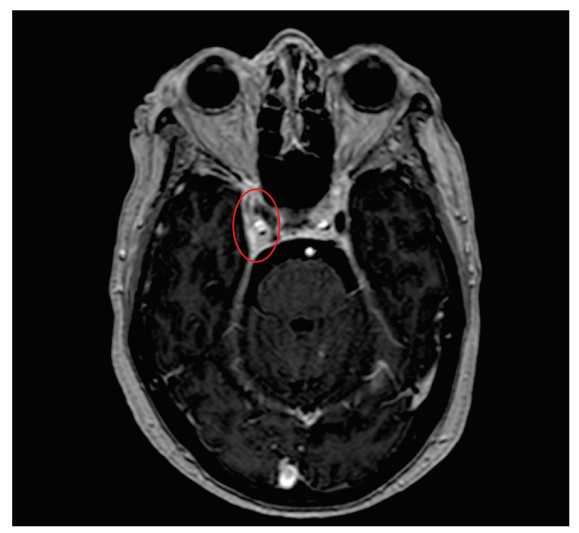

Figure 2A: Initial axial contrast-enhanced MRI

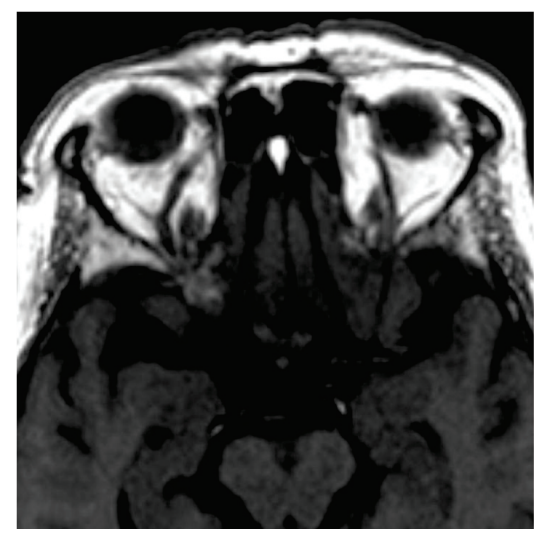

Figure 2B: Initial axial MRI showing a dilated right superior ophthalmic vein

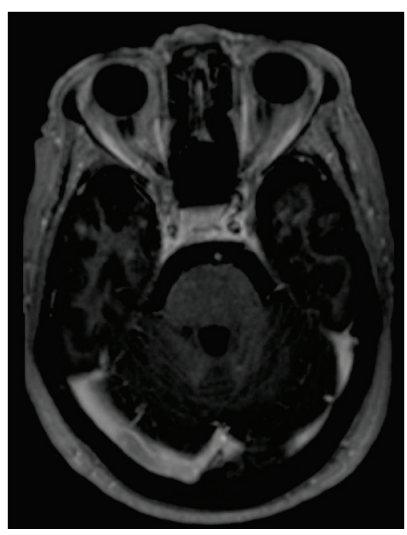

Figure 2C: Axial MRI 3 months later, without the filling defect 
After 3 months of follow up she remained asymptomatic, with reduced congestion in the RE and an unchanged fundus examination. A subsequent MRA reported that "filling defects of the right cavernous sinus are no longer observed" (Figure 2C).

\section{Discussion}

The diagnosis of CST is challenging due to its mild and nonspecific clinical presentation, which includes fever, proptosis, cranial nerve palsies in about $80-100 \%$ of patients, decreased visual acuity, diplopia in about $50-80 \%$ of patients, hemiparesis, and seizures in less than $20 \%$ of cases according to a study by Southwick et al. ${ }^{(7)}$.

The septic form is the most frequent, but in about 4.8$12.5 \%$ of cases the aetiology remains $\operatorname{unclear}^{(7,8)}$.

In this case report, infectious causes (including hepatitis B virus, Epstein- Barr virus, human immunodeficiency virus, cytomegalovirus, herpes simplex, toxoplasmosis, and syphilis) were extensively investigated, as well as autoimmune and prothrombotic factors (protein $\mathrm{C}$ and $\mathrm{S}$ and factor $\mathrm{V}$ Leiden deficiency, increased factor VIII), but the results were negative. The patient also underwent echocardiography and bilateral carotid Doppler, both without significant changes. Based on these results the condition was considered idiopathic, and treatment with enoxaparin $60 \mathrm{mg}$ subcutaneously was indicated. It has been shown that enoxaparin reduces mortality rates and is associated with an increased rate of recovery ${ }^{(9-11)}$.

The diagnosis of CST depends on a strong initial suspicion, and MRA is the gold standard method to identify the filling defect of the cavernous sinus ${ }^{(6)}$, as was the case here.

The differential diagnosis should include orbital cellulitis, orbital apex syndrome, and carotid-cavernous fistula, among others $^{(12)}$.

In this case, blood flow to the cavernous sinus improved after anticoagulation, which is consistent with the literature. Stols et al. found an improvement rate of $60 \%$ in cases of dural sinus thrombosis ${ }^{(13)}$

The prognosis of CSF has improved and its current mortality rate is about $30 \%{ }^{(2)}$, although survivors may present complications such as meningitis, septic emboli, blindness, and sepsis, which can lead to permanent disability ${ }^{(14)}$.

\section{ReFERENCES}

1. Yanoff M, Duker JS, Augsburger JJ, editors. Ophthalmology. 3rd ed. Edinburgh: Mosby; 2009. p. 1076-80.

2. King MD, Day RE, Oliver JS, Lush M, Watson JM. Solvent encephalopathy. Br Med J (Clin Res Ed).1981;283(6292):663-5.

3. Boniuk M. The ocular manifestations of ophthalmic vein and aseptic cavernous sinus thrombosis. Trans Am Acad Ophthalmol Otolaryngol. 1972;76(6):1519-34.

4. Melamed E, Rachmilewitz EA, Reches A, Lavy S. Aseptic cavernous sinus thrombosis after internal carotid arterial occlusion in polycythaemia vera. J Neurol Neurosurg Psychiatry. 1976;39(4):320-4.

5. Seow VK, Chong CF, Wang TL, Lin CM, Lin IY. Cavernous sinus thrombophlebitis masquerading as ischaemic stroke: a catastrophic pitfall in any emergency department. Emerg Med J. 2007;24(6):440.

6. Uzan M, Ciplak N, Dashti SG, Bozkus H, Erdincler P, Akman C. Depressed skull fracture overlying the superior sagittal sinus as a cause of benign intracranial hypertension. Case report. J Neurosurg. 1998;88(3):598-600.

7. Southwick FS, Richardson EP Jr, Swartz MN. Septic thrombosis of the dural venous sinuses. Medicine (Baltimore).1986;65(2):82-106.

8. Brismar G, Brismar J. Aseptic thrombosis of orbital veins and cavernous sinus. Clinical symptomatology. Acta Ophthalmol (Copenh). 1977;55(1):9-22.

9. Einhäupl KM, Villringer A, Meister W, Mehraein S, Garner C, Pellkofer M, et al. Heparin treatment in sinus venous thrombosis. Lancet. 1991;338(8767):597-600. Erratum in Lancet 1991;338(8772):958. Comment in Lancet. 1991;338(8775):11534. Lancet. 1991;338(8775):1154.

10. Stam J, de Bruijn SF, DeVeber G. Anticoagulation for cerebral sinus thrombosis. Cochrane Database Syst Rev. 2002;(4):CD002005. Review. Update in: Cochrane Database Syst Rev. 2011;(8):CD002005.

11. Levine SR, Twyman RE, Gilman S. The role of anticoagulation in cavernous sinus thrombosis. Neurology. 1998;38(4):517-22.

12. Lai PF, Cusimano MD. The spectrum of cavernous sinus and orbital venous thrombosis: a case and a review. Skull Base Surg. 1996;6(1):53-9.

13. Stolz E, Trittmacher S, Rahimi A, Gerriets T, Röttger C, Siekmann $\mathrm{R}$, Kaps M. Influence of recanalization on outcome in dural sinus thrombosis: a prospective study. Stroke. 2004;35(2):544-7.

14. Laupland KB. Vascular and parameningeal infections of the head and neck. Infect Dis Clin North Am. 2007;21(2):577-90, viii.

\section{Corresponding Author:}

Filipe Mira

E-mail: filipemiraferreira@gmail.com 